\title{
'I'll play the game, but I cannot stay"1: The role of third space professionals in encouraging the retention, success and sense of belonging of undergraduate students
}

I'll survive

When the world's crashin' down

When I fall and hit the ground

I will turn myself around

Don't you try to stop me!

(Alice, Avril Lavigne, 2010) ${ }^{2}$

Julie Hughes ${ }^{a}$, Debra Cureton ${ }^{b}$, Jenni Jones ${ }^{c}$

a.The College of Learning and Teaching, University of Wolverhampton, ${ }^{\text {b. The Doctoral }}$

College, University of Wolverhampton, ${ }^{c}$. The Faculty of Arts, Business and Social Sciences, University of Wolverhampton, UK

\begin{abstract}
In 2019, a diverse, post-92, Midlands university implemented a new, hybrid third space role called the 'academic coach' (AC) to support its mission to make its educational provision fully accessible to all its students, to retain them and to ensure their success. Since a sense of belonging to their institution is such a powerful influence on students' sense of wellbeing, their development of an academic identity and their resilience in the higher education context, with consequent positive impact upon their retention and success, this role is devoted to the pastoral care and personal tutoring of levels three and four students. This case study considers the journey of the $A C$ in defining and shaping this new role and offers the ACs' perceptions of their influence on the experience of students at levels three and four by enhancing collaborative and learning relationships within the wider university.
\end{abstract}

Keywords: third space professionals, transitions, levels three and four undergraduates, retention, success, belonging

\footnotetext{
${ }^{1}$ Quote from Alice through the Looking Glass by Lewis Carroll (1871) and from the Avril Lavigne song 'Alice', 2010. It has been chosen as the title for the paper, as it represents students' struggle to understand the rules of academia, with consequent adverse impact upon their retention and success (Cousin and Cureton, 2010). NB. The word 'cannot' is replaced by 'can' $t$ ' in the Avril Lavigne song.

2 This quote from the Avril Lavigne Song 'Alice' (2010) is used here as it highlights both the resilience shown by many of the students at the case study university as they strive to change their lives through education and the determination shown by the academic coaches in carving out the space and practices involved in the role they play to support our students so skilfully.
} 


\section{Introduction}

The University of Wolverhampton is proud of its long history of excellence in widening access to higher education (HE). To this end, social justice is central to the University's mission and so it defines itself as the 'University of Opportunity that it serves its local community well, having 'place' embedded within its strategic plan. As a consequence, the University is highly diverse and, of its c. 22,000 students in $2020,60 \%$ are from index of multiple deprivation (IMD) quintiles 1 and $2,48.4 \%$ are mature students, $68 \%$ of students are first in family to attend university, and $90 \%$ of students commute from a twenty-five-mile radius to study. Over half $(51.1 \%)$ of the students who attend the University are from the global majority groups (formerly known as BAME) and a wide range of ethnic groups contributes to this $51.1 \%$ of students ${ }^{3}$. In order to serve the community through the graduates that the institution produces, equality in the retention and the success of its students is a key strategic goal.

To support student retention and success, an innovative approach to students' transition and support was taken, through the development of three hybrid roles: the 'graduate teaching assistant' (GTA), the 'academic coach' (AC) and the 'student transition teacher' (STT). The GTA role was launched in 2014 and to date has offered 120 recent undergraduates a twoyear post with the opportunity to undertake a Postgraduate Certificate in Education (PGCE) for the post-compulsory sector. Unique to the HE sector, this role is focused upon teaching and supporting students. The AC role was created - initially as a pilot - in 2018, to build upon the GTA role and to offer a career development opportunity for GTAs and Professional Services staff. From an initial pilot, with nine ACs in two faculties, there are now twenty-eight permanent ACs acting as personal tutors for all new students at levels three and four. The STT role, with seventeen across all faculties, is a 2020 initiative offering a further permanent career route for ACs and GTAs. The focus of all three hybrid roles is to support students through the earlier stages of transition into HE at levels three (Foundation Year) and four, so developing an academic learning relationship and building student understanding of the nuances of $\mathrm{HE}$ learning. By these means, students' prior expectations of HE may be met where possible (or, if unrealistic, gently modified) and, it is hoped, students will develop their sense of belonging, known to positively affect retention and success (Thomas, 2012; Thomas et al., 2017).

The GTA, STT and AC roles are carried out within the domain between academic and professional spheres, termed the 'third space' (Whitchurch, 2008, p.3). As they are performed by staff who are neither academics nor administrators, we discuss in the next section the 'third space' nature of the roles and how they support HE students. Particular reference will be made to the $A C$ role, which will be the focus of the rest of this case study.

\section{Literature review}

The current United Kingdom (UK) HE context is in a state of flux, not only as a result of the 2020/21 COVID-19 pandemic, but also on account of the looming Research Excellence Framework (REF) assessment in 2021, the introduction of the Teaching Excellence Framework (TEF) (GovUK, 2017a) and the introduction of the Knowledge Exchange Framework (KEF) in 2020 (UKRI, 2019). Increasingly, universities are feeling the pressure of

\footnotetext{
${ }^{3}$ University of Wolverhampton (2020) Internal data provided by the University's Planning Office
} 
sector-wide comparisons with funding implications. Of particular interest is that the amount of funding universities receive is now linked to their TEF results, with the aim of increasing teaching excellence (Gunn 2018). Additionally, with the shift in emphasis in the Office for Students' regulatory framework (2018) to a focus upon the student lifecycle, our University felt that the introduction of new third space roles, created to support student transition into and passage through university (Matheson et al., 2018) could enhance student retention and success, which, in turn, would improve our funding position.

Gravett and Winston (2019) usefully conceptualise student transition as troublesome and fluid against a literature and policy backdrop of 'bridges' and phases to be settled (Briggs et al., 2012; Yorke, 2000). They contend that sectoral and institutional drivers and metrics do not address students' complex and messy, lived and living, realities. Gravett and Ajjawi (2021, p.6) develop this further and present students as nomadic subjects in motion. They argue that 'overlaps and tensions' in transient states may fruitfully offer new insights for practice.

Simultaneously, key transition roles and activities such as personal tutoring remain underdeveloped and under-researched (Walker, 2020, p.1) in the sector despite UK HE's being unique in operating personal tutoring (Grey and Osborne, 2020). The emerging situation is characterised by a lack of clarity over the role and concern over the developmental support required to assist staff in an activity perceived as an intersection between the academic and pastoral.

Whitchurch (2013) documents the creation of hybrid or intersection roles in HE and transition into them, identifying that to explore a third space identity grapples with - and is able to accommodate - the tensions of being in a modulated or mutated professional role where a loosening of earlier boundaries is evident. Fanghanel's (2012, p.2) exploration of turbulent moments of practice in academic identities stresses the elasticity of the role - an indication of how boundaries and categories of staff in the HE workforce at the time were blurring. ACs inhabit a modulated space with fuzzy and evolving identities, for they are not academics and not professional services personnel, but instead are taking a role which diversifies and spans the student lifecycle and transition into and passage through university.

As alumni and recent employees, their own transition into a new role is worthy of study, for they may offer new, "knowledges, relationships, legitimacies, and languages that they create" (Whitchurch, 2013 p.xiii). This case study seeks to explore the unpredictability and contestability of the developing $\mathrm{AC}$ role and its ability to offer multiple viewpoints of the institution and its support of student belonging.

\section{Description of the sample}

ACs from cohorts one (2018) and two (2019) were invited to an information-gathering event (detailed below).

Fourteen ACs from all faculties of the University attended the event. Of these, five were from cohort one and nine were from cohort two. Cohort one ACs had been in post since 2018/2019, whilst cohort two ACs had been in post since 2019/2020. Nine ACs were female and five were male. 


\section{Implementation method of analysis/evaluation}

The data was collected by means of a modification of the 'Consensus Oriented DecisionMaking Approach' (Hartnett, 2010) to include data collection points. This formed the 'Consensus Orientated Research Approach' [CORA - see below] (Cureton and Cousin, 2012). This approach was adopted as consensus approaches are rooted in social justice practices (Susskind, 2008), aim to replace hierarchy with shared power, value equality, freedom and co-operation and respect everyone's point of view (Seeds of Change, 2013). Focus groups of varying sizes were also used as they empower participants' voice and promote opportunities to make social change (Wilkinson, 1998; 1999). Given the aim of the AC role, the implementation of a social justice-focused research approach and research tools to enhance participant empowerment were necessary.

\begin{tabular}{|c|c|c|c|c|c|}
\hline $\begin{array}{l}\text { Consensus- Oriented } \\
\text { Decision- Making }\end{array}$ & $\begin{array}{c}\text { Consensus Oriented Research } \\
\text { Approach (CORA) }\end{array}$ & Process & \multicolumn{3}{|c|}{ Research Dynamics } \\
\hline $\begin{array}{l}\text { 1. Framing the Topic } \\
\text { 2. Open Discussion }\end{array}$ & $\begin{array}{l}\text { Introducing the research problem } \\
\text { Exploring the research problem }\end{array}$ & Educating & $\begin{array}{l}\text { Informing } \\
\text { participants of the } \\
\text { research }\end{array}$ & \multirow{2}{*}{$\begin{array}{l}\text { Creating a safe } \\
\text { space for students } \\
\text { to feel confident } \\
\text { listened to and } \\
\text { trusts the team }\end{array}$} & $\begin{array}{l}\text { Collecting opinion } \\
\text { and attitude \& } \\
\text { perceptions data } \\
\text { about the topic }\end{array}$ \\
\hline $\begin{array}{l}\text { 3. Identifying Underlying } \\
\text { Concerns }\end{array}$ & Identify the key areas of the problem & Engages & $\begin{array}{l}\text { Engaging students } \\
\text { with issue in a } \\
\text { playful manner } \\
\text { and }\end{array}$ & & $\begin{array}{l}\text { Collecting } \\
\text { information about } \\
\text { student concerns }\end{array}$ \\
\hline $\begin{array}{l}\text { 4. Collaborative Proposal Building } \\
\text { 5. Choosing a Direction } \\
\text { 6. Synthesizing a Final Proposal }\end{array}$ & $\begin{array}{c}\text { Provide solutions } \\
\text { Winding up and moving on }\end{array}$ & Empowers & $\begin{array}{l}\text { encouraging } \\
\text { students to reflect }\end{array}$ & $\begin{array}{l}\text { Allowing students } \\
\text { to take control of } \\
\text { the research space }\end{array}$ & $\begin{array}{l}\text { Collecting } \\
\text { consensus data } \\
\text { about solutions }\end{array}$ \\
\hline 7. Closure & & & \multicolumn{3}{|c|}{$\begin{array}{l}\text { Winding up the event: by consolidating the discussion of the day. } \\
\text { Moving on from the day:by encouraging participants support in } \\
\text { the implementations of propsed changes. }\end{array}$} \\
\hline
\end{tabular}

Figure 1:The dynamics of the CORA process

The data was collected over the course of a full-day event and involved gathering informed consent, so creating a safe place in which to share experiences, opinions, attitudes and perceptions. Playful techniques were used to encourage feeling of safety. Discussion groups of various sizes explored the subject matter. Further details of this process are detailed below.

At the start of the first session, ACs played snakes and ladders in small groups as a means of exploring enablers (ladders) and hindering factors (snakes) within their roles; a player hitting a snake or a ladder was asked to note a relevant incident on a Post-It note. The facilitators then organised these into themes which the full group discussed (with notes taken) for thirty minutes. 
In the second session, 'auto-driven photo elicitation' (Ford et al., 2019) was the focus for three small groups ( $n=5,6$ and 6 ). ACs had been asked to bring photographs depicting two positive aspects of their role and two aspects that caused them concern. The ACs shared and collated their pictures in the groups, discussing what their photographs represented and any critical incidents that had particularly drawn their attention. The participants and focus group facilitators summarised the discussions on flipcharts and the conversations were recorded. Each group presented its thoughts back to the full group to facilitate further discussions of the findings. Again, these discussions were transcribed by note takers and recorded.

The final full-group discussion session gave the ACs the opportunity to consider what would support the delivery of their role and support their practice, with consideration of possible solutions and how best to move forward.

Through these sessions, we were able to collect ACs' perceptions, opinions, beliefs, and attitudes through which we were able to identify what the ACs did well, how they did it, what supported them in doing what they did and what got in the way of their further enhancing the role.

\section{Analysis and presentationof the data}

\section{Analysis of the data}

From an initial review of the data, it was evident that the ACs had mostly used metaphors to describe their experiences. To this end, we carried out an inductive thematic analysis (Braun and Clarke, 2006) of the presented metaphors. Metaphor analysis is a qualitative research approach that focuses on the metaphoric linguistic expressions (MLEs) presented by participants. Through these, the researchers aim to unpick the participants' thought patterns and understandings of a given topic (Cameron and Low, 1999; de Guerrero and Villamil, 2002). The presented metaphors were explored as they ' $\ldots$ are a valuable research tool for gaining new insights into education practice and theory" (Jensen, 2006 p.13). As many of the metaphors presented pertained to Alice's adventures in Wonderland (for example, going down rabbit holes, navigating a maze, metamorphorizing from a caterpillar to a butterfly), the researchers developed wonderland-inspired theme names.

\section{Presentation of the data}

Seven themes emerged from the data which provide insight into how the ACs navigated the curation of their role. 


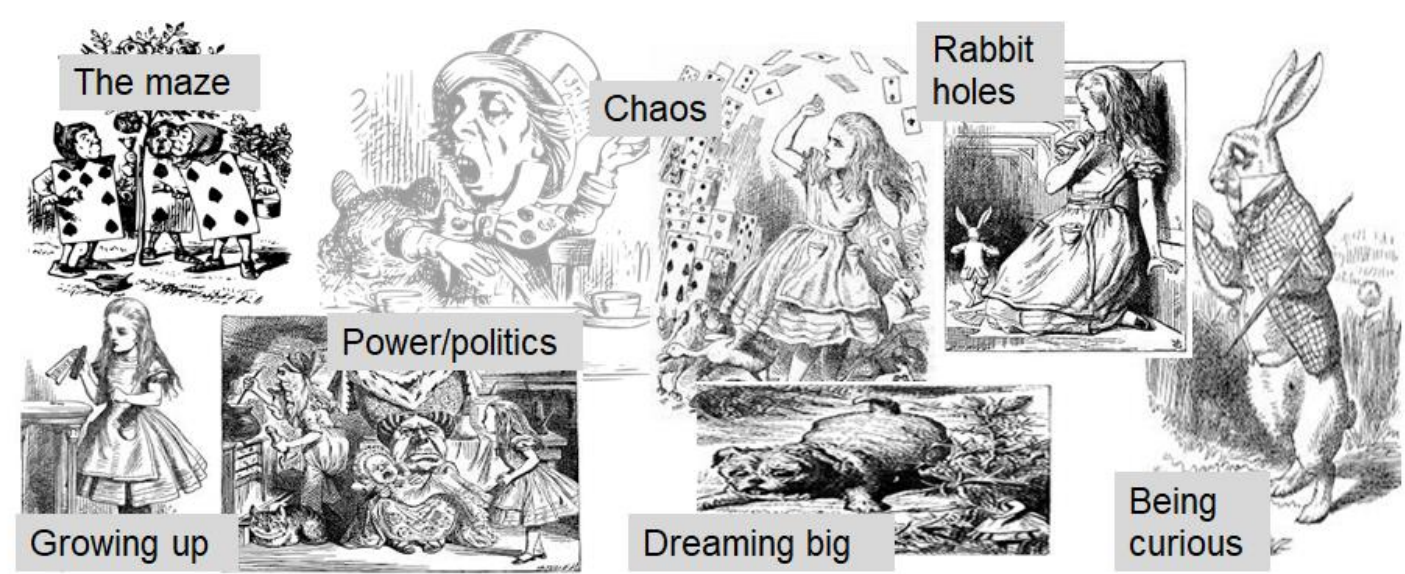

Figure 2: The themes that emerged from the thematic analysis

In the beginning, ACs likened their role curation to a journey in which they were navigating 'a maze' and 'unchartered territories'. This blurring/loosening of boundaries (Whitchurch, 2013) they described as 'jumping into an abyss'. ACs started out without a map as they attempted to find their way from appointment to embedding the role into their respective faculties. They felt that they were alone.

Along the way, they faced many barriers - 'mountains that they had to climb' - that often centred on role uncertainty (for both $A C$ and faculty staff), unhelpful attitudes at times from others and the fact that the University systems 'do not talk to each other'. This left ACs feeling frustrated, and 'banging their head against a brick wall', whilst constantly having to 'jump through hoops' in response to 'red tape', which hindered their support of students.

One important factor in navigating this maze was comradeship. The ACs formed a community of practice and shared their learning, as well as garnered support and guidance from the role creators and coordinators. They felt they were 'all in the same boat' and that they would 'sink or swim' together. Their ability to swim arose from the 'Dunkirk spirit' that comradeship has afforded them.

On their journey, they encountered 'chaos', most notably in the form of University systems, which appeared monolithic, anchored and siloed. Their rigid and at times unyielding nature scratched and grazed the ACs' desire to be the human 'face and touch' of the institution. They rightly identified the need for the' right tools for the job' and questioned how much AC activity could be mechanised in what appeared to them to be an already industrial-scale, data-driven coupling of student and institution. The ACs found themselves at the 'chalk face' of interventions and noted that 'one size doesn't fit all'; the 'right tools for the job' might not always be available and might need to be sourced elsewhere or even invented/created.

The AC's encountered two forms of 'rabbit holes' on their journey. The first related to seeking information to no avail (as noted above); the other related to spaces where the ACs felt safe. As this journey was not without professional etiquette lessons, there was some 'stepping on toes', together with loggerhead exchanges, uncomfortable feelings of being 'an unwanted messenger', 'a spy' who was 'swimming against the tide', and 'hitting their head against a brick wall'. It is thus clear that having safe spaces is important. The ACs created one safe space by offering a mutually neutral ground in the form of the Coaches Kitchen. 
Here the ACs cooked and ate with those who attended, thus allowing for dialogue, as ACs, other staff and students could come together there to talk, to share, to be and to foster a sense of belonging to wider groups within the University. However, there were still tensions and this highlights the importance of the ACs' offices, 'their bolt holes', to which they retreated to glean support from each other.

The ACs experienced the University as 'bound by red tape' and 'a closed book'. To navigate this part of their journey, they do have to understand institutional 'power and politics'. The ACs appreciated the need for red tape, but wished that the systems had more fully supported their welcoming and nurturing role. They were aware that they too were 'part of the machinery' of the University and should also 'oil the wheels'. However, for ACs, 'oiling the wheels' simply meant cracking codes and solving mazes as the best means of achieving benefit for their students.

It was the ACs' humanness which allowed them to see the systems and their internal politics as 'something to be played'. Consequently, the ACs questioned and challenged the systems where they found contradictory information. In some instances, this constructive criticism has been welcomed and acted upon whilst in other settings it has been rejected. The ACs analogy of the jigsaw is important here: they saw themselves as 'finding the missing pieces'. They carried and accumulated odd bits of information which formed a larger picture only in the context of conversation and collaboration with others. Sometimes this felt too much, like 'swimming through mud'. Despite the mud and chaos they described, they also felt that they were constructing and co-constructing new tools, new working practices and new resistances.

Although the role was outlined in a job description, the ACs shaped it and enhanced others' understanding of what they were able to achieve through 'being curious'. In this, they were curators; they found what gaps students fall through and became a 'bridge' connecting the pathways between the students and the institution. They helped others understand the consequences of this by 'shining a spotlight' on the barriers and provided solutions to 'open up the gateway' towards filling those gaps. They attempted to 'break down the walls' by sharing their learning, not just with the students, but with others within the wider institution. However, as with any journey, not everyone wants to take or support the 'path less trodden.' Some people listen and make changes, but sadly others do not.

Like 'chameleons', the ACs delivered their role by responding to the need presented to them. They often did this by drawing on their wits and implementing prior knowledge. There was a strong sense that the role was hard work, exhausting at times, on account of the 'long winding road' of the 'maze', if students were to be supported to navigate beyond the 'brick walls' that they sometimes encountered. The ACs likened their role to 'pedagogic bungee jumping' whereby they were adapting to this new role while working hard to meet the needs of both the students and the rest of the institution, with differing levels of 'pull and push' from both groups.

The ACs recognised that 'growing up' is important to the journey for both them and their students. They 'sculpted' the role, 'broke down boundaries' and 'paved the way' for students to settle in more quickly and grow. In recognition, the ACs acknowledged that relationships take time and effort to grow and that this is a work in progress. They commented on the 'family' atmosphere between ACs as they shared with and supported each other; equally, 
they recognised that their role with their students was to move beyond the merely supportive role of a 'parent' to reach the point of 'passing them the baton' so they could independently continue their own personal journey. So, ACs were simultaneously growing and stretching themselves into new spaces and places whilst facilitating, for their students, this growth beyond them.

Despite the challenges of relationships, the ACs felt this to be the most transformational sphere they inhabited and had influence over; through this, they could 'dream big', while also encouraging their students to 'go for gold.' This proved to be where they felt they had the most autonomy and freedom. They felt that it was 'vital to be trusted'. This trust might lead to further professional relationship building as ACs found themselves valued as lenses into the student experience, able to problem-spot and problem-avert. They were a 'lighthouse that sheds the spotlight on issues' and sought to offer safe navigation and even rescue those in distress.

ACs were 'providing a personalised service rather than customer care', through which they were giving their students 'a leg up' and helping them 'achieve their dreams'. The ACs achieved this by responding to the students' needs. Often this was an individual need, but ACs also responded to the University's need, as students who join us may have greater support needs. ACs explored student need and found solutions to the students' problems by putting together the pieces 'like a jigsaw puzzle'. They performed 'triage', and in doing so felt that they had their 'fingers on the pulse'. As a result, the ACs were 'many things to many people'. However, much of their ability to understand the difficulties faced by students was located in their own recent experience as students at the University. This provided a common ground where rapport and trust between student and AC could grow.

\section{Conclusions and limitations}

The aim of this case study paper was to share the collective journey of the ACs as they worked to define and shape their role and to share the ACs' perceptions of their impact on the experience of levels three and four students. The findings highlight how powerful the AC role is in improving students' retention and success and creating a sense of belonging at these levels. It is clear, despite the obstacles from within the systems, processes and sometimes difficult 'others', they were able to offer much-needed support and guidance to those students in the early stages of transition into the University. ACs managed to do this through building trusting relationships with students, through creation of safe spaces for themselves and others, through supporting each other, through problem-solving with and for the students and by shining the spotlight on key barriers in order to make changes for the future. Despite the hard work needed, their huge efforts and persistence did make changes for students and ultimately the institution and led to an increased sense of belonging, known to enhance retention and success (Thomas, 2012; Thomas et al., 2017).

However, although metaphors are a valuable research tool (Jensen, 2006), there are limitations to this study, since it focuses solely on metaphors and on only one of the three groups initially mentioned. Metaphors are short and culturally specific and thus could be easily misaligned by three associate professors, however seasoned, who, unlike the ACs, were new graduates three decades ago. However, care has been taken to share the metaphors directly provided by the ACs, together with the 'Alice in Wonderland' metaphors, in order to show clearly from where they were derived. The intention is that analysis will be 
carried out, investigating the key themes coming through from the CORA approach used, and connections made to identifiable specific impact upon student progression and retention figures. These are not available as yet. In addition, similar work will be done to measure the impact of the GTA and STT roles too, so there is a better sense of the contribution collectively and individually of these three key student support roles.

Though this work provides just an initial top-line analysis of the AC role, it does clearly highlight the difficulties that the ACs encountered in curating a third space role and shows how they worked hard to embed this into the academic arena. It also emphasises how those in supporting roles may well need to access support themselves if they are to be able to support others consistently.

In memory of Dr Derek Walton, who, along with Julie Hughes, created and championed the academic coach role, supported the coaches' development and called them his 'terriers', in recognition of their tenacious ability to keep digging until they found the root cause of a problem or a much-needed solution. He will always be at the heart of academic coaches' practice.

\section{Reference list}

Briggs, A.R.J., Clark, J. and Hall, I. (2012) 'Building Bridges: Understanding Student Transition to University.' Quality in Higher Education 18(1), 3-21. Available at: Building bridges: understanding student transition to university: Quality in Higher Education: Vol 18, No 1 (tandfonline.com) (Accessed: 30 March 2021).

Braun, V. and Clarke, V. (2006) 'Using thematic analysis in psychology.' Qualitative Research in Psychology, 3, 77-101. Available at: Using thematic analysis in psychology: Qualitative Research in Psychology: Vol 3, No 2 (tandfonline.com) (Accessed: 30 March 2021).

Cameron, L. and Low, G. (1999) 'Metaphor.' Language Teaching, 32, 77-96. Available at: Metaphor|Language Teaching | Cambridge Core (Accessed: 30 March 2021).

Cousin, G. and Cureton, D. (2012a) 'Disparities in student attainment (DiSA).' York: Higher Education Academy. Available at: wolverhampton 2010 disa final report.pdf (heacademy.ac.uk) (Accessed: 10 October 2020).

Cureton, D. (2012) 'Consensus Oriented Research Approach.' Briefing Paper. Wolverhampton: University of Wolverhampton. Available at: Creative co-inquiry with students (openrepository.com) (Accessed: 20 November 2020).

Cureton, D. (2017) 'The WhatWorks? Organisational Change Programme Final Report for the University of Wolverhampton.' York: Higher Education Academy. Available at: https://wlv.openrepository.com/bitstream/handle/2436/621990/Inclusive\%20assessment\%20 approaches.pdf?sequence=6\&isAllowed=y (Accessed: 10 October 2020). 
de Guerrero, M.C.M. and Villamil, O.S. (2002) 'Metaphorical conceptualizations of ESL teaching and learning.' Language and Teaching Research 6, 95-120. Available at: Metaphorical conceptualizations of ESL teaching and learning - María C. M. de Guerrero, Olga S. Villamil, 2002 (sagepub.com) (Accessed: 30 March 2021).

Dhanda, M. (2009) 'Understanding disparities in student attainment: what do black and minority ethnic students say?' Paper presented at the Annual Meeting of the ISPP 32nd Annual Scientific Meeting, Trinity College, Dublin, Ireland, 2011-05-24. Available at: Understanding Disparities in Student Attainment: (wlv.ac.uk) (Accessed: 30 November 2020).

Fanghanel, J. (2012) Being an Academic. New York and London: Routledge. ISBN: 9780415573719.

Ford, K., Bray, L., Water, T., Dickinson, A., Arnott, J. and Carter, B. (2017) 'Auto-driven Photo Elicitation Interviews in Research with Children: Ethical and Practical Considerations.' Comprehensive Child and Adolescent Nursing, 40(2), 111-125. Available at: Auto-driven photo elicitation interviews in research with children: ethical and practical considerations Edge Hill University (Accessed: $21^{\text {st }}$ February, 2021).

Gov. UK (2017a). 'Review of the teaching excellence framework year 2.' London: Universities UK. Available at: review-of-the-teaching-excellence-framework-year-2.pdf (universitiesuk.ac.uk) (Accessed: 10 October 2020).

Gravett, K. and Ajjawi, R. (2021) 'Belonging as situated practice.' Studies in Higher Education. Available at: https://doi.org/10.1080/03075079.2021.1894118 (Accessed: $21^{\text {st }}$ February, 2021).

Gravett. K. and Winstone, N.E. (2019) 'Storying students' becomings into and through higher education.' Studies in Higher Education, 1-12. Available at:

https://doi.org/10.1080/03075079.2019.1695112 (Accessed: $21^{\text {st }}$ February, 2021).

Grey, D. and Osborne. C. (2020) 'Perceptions and principles of personal tutoring.' Journal of Further and Higher Education, 44(3), 285-299. Available at:

https://doi.org/10.1080/0309877X.2018.1536258 (Accessed: 21 ${ }^{\text {st }}$ February, 2021).

Gunn, A. (2018) 'The UK Teaching Excellence Framework (TEF): The Development of a New Transparency Tool.' In: Curaj, A., Deca, L. and Pricopie, R. (eds.) European Higher Education Area: The Impact of Past and Future Policies. Cham: Springer, 505-526. Available at: https://doi.org/10.1007/978-3-319-77407-7 31 (Accessed: 30 March 2021).

Hartnett, T. (2010) Consensus-oriented Decision-Making Model. Gabriola, BC: New Society Publishers. ISBN: 9780865716896

Jensen, D.F. (2006) 'Metaphors as a bridge to understanding educational and social contexts.' International Journal of Qualitative Methods, 5, 1-17. Available at: Metaphors as a Bridge to Understanding Educational and Social Contexts - Devon Jensen, 2006 (sagepub.com) (Accessed: 30 March 2021). 
Office for Students (2018) 'The regulatory framework fo higher education in England.' Available at: The regulatory framework for higher education in England - Office for Students (Accessed: $21^{\text {st }}$ February, 2021).

Matheson, R., Tangney, S. and Sutcliffe, M. (2018) Transitions in, through and out of higher education. London: Routledge. ISBN: 9781138682184

Susskind L.E. (2008) 'Keynote Address: Consensus Building, Public Dispute Resolution, and Social Justice.' 35 Fordham Urb. L.J. 185 Available at:

https://ir.lawnet.fordham.edu/ulj/vol35/iss1/7 (Accessed: 30 March 2021).

Thomas, L. (2012) 'Building Student Engagement and Belonging at a Time of Change in Higher Education.' London: Paul Hamlyn Foundation. Available at:

https://www.heacademy.ac.uk/system/files/what works final report.pdf (Accessed: 10 October 2020).

Thomas, L., Hill, M., O’ Mahony, J. and Yorke, M. (2017) Supporting Student Success: strategies for institutional change: What Works? Student Retention and Success programme. Final Report. London: Paul Hamlyn Foundation. Available at: Summary-reportfinal-no-crop-1.pdf (phf.org.uk) (Accessed: 10 October 2020).

UKRI (2019) 'Effective knowledge exchange to put universities at the heart of our country's future' - Universities Minister Chris Skidmore's speech to Engagement Forum, 26 September 2019. Available at: [ARCHIVED CONTENT] "Effective knowledge exchange to put universities at the heart of our country's future" - Universities Minister Chris Skidmore's speech to Engagement Forum - Research England (nationalarchives.gov.uk) (Accessed: 6 November 2020).

Walker, B.W. (2020) 'Tackling the personal tutoring conundrum: A qualitative study on the impact of developmental support for tutors.' Active Learning in Higher Education, 1-13. Available at: https://doi.org/10.1177/1469787420926007 (Accessed: 30 March 2021).

Whitchurch, C. (2008) 'Shifting identities and blurring boundaries: The emergence of third space professionals in UK higher education.' Higher Education Quarterly, 62, 377-396.

Available at: https://doi.org/10.1111/1.1468-2273.2008.00387.x (Accessed: 30 March 2021).

Whitchurch, C. (2013) Reconstructing Identities in Higher Education. The Rise of the Third Space Professionals. London: Routledge. ISBN: 978-0415614832

Wilkinson, S. (1998) 'Focus group methodology: A review.' International Journal of Social Research Methodology, 1(3), 181-203. Available at: Focus group methodology: a review: International Journal of Social Research Methodology: Vol 1, No 3 (tandfonline.com) (Accessed: 30 March 2021).

Wilkinson, S. (1999) 'Focus Groups: A feminist method.' Psychology of Women Quarterly, 23, 221-244. Available at: Focus Groups: A Feminist Method - Sue Wilkinson, 1999 (sagepub.com) (Accessed: 30 March 2021). 
Yorke, M. (2000) 'Smoothing the Transition into Higher Education: What Can Be Learned From Student Non-Completion.' Journal of Institutional Research, 9, 35-47. Available at: Word Pro - Yorke.Iwp (aair.org.au) (Accessed: 30 March 2021). 